\title{
Hymenoptera Chalcidoidea inhabiting galls of Cynipidae in Jordan
}

\author{
Maria C. Rizzo \& Richard R. Askew
}

Rizzo, M. C. \& Askew, R. R. 2008: Hymenoptera Chalcidoidea inhabiting galls of Cynipidae in Jordan. — Entomol. Fennica 19: 218-227.

Twenty-three species of Chalcidoidea (5 Eurytomidae, 4 Torymidae, 2 Ormyridae, 5 Pteromalidae and 7 Eulophidae) are recorded as regular members of the parasitoid fauna inhabiting galls of Cynipidae in Jordan. The occurrence of three additional species, probably only facultatively associated with cynipid galls, is noted. Twenty-two out of the total 26 species were previously unrecorded in the country, while 13 of them are also new for the entire Middle East. Eighteen new host records were detected, together with 24 new plant-parasitoid associations. The biology of each species is briefly commented upon, as well as the presence of a host-related colour variation in some species.

M. C. Rizzo, SENFIMIZO Department, University of Palermo, Viale delle Scienze 13, I-90128 Palermo, Italy; E-mail: macoriz@unipa.it

R. R. Askew, 5 Beeston Hall Mews, Beeston, Tarporley, Cheshire CW6 9TZ, United Kingdom; E-mail: askew@beeston22.wanadoo.co.uk

Received 19 April 2007, accepted 1 November 2007

\section{Introduction}

Gall-inducing species of Cynipidae are wellknown to suffer considerable mortality from chalcidoid parasitoids (Askew 1984, Stone et al. 2002, Csóka et al. 2005). Gall wasps of Quercus Linnaeus (Fagaceae), the Cynipini, are particularly severely attacked and their associated communities of inquilines and parasitoids are often large (Askew 1984, Stone et al. 2002, Csóka et al. 2005). Whilst the parasitoid communities of cynipid gall wasps in the Western Palaearctic are relatively well-known (Stone et al. 2002, Csóka et al. 2005, Askew et al. 2006a), those of the Middle East have been studied very little (cf. Noyes 2003). In this paper we present details of the Chalcidoidea reared from some samples of cynipid galls collected by Bruno Massa (Palermo) in Jordan during three visits between 1999 and 2000 (Nieves-Aldrey \& Massa 2006).
All the collected galls were induced by Cynipini on Quercus spp. (Fagaceae), except for one sample induced by a species of Aylacini on stems of Salvia sp. (Lamiaceae).

\section{Materials and methods}

About 400 galls of Cynipidae were collected by Bruno Massa in Jordan during the periods 22.V.3.VI.1999, 23.X.-4.XI.1999 and 23.IV.-3.V. 2000. The collecting area extended over 1,950 $\mathrm{km}^{2}$ and lied in the highlands. Climate and vegetation are typically Mediterranean, even if large areas are now agricultural land. Forests of Pinus halepensis Miller and evergreen oak Quercus calliprinos Webb occur up to $1200 \mathrm{~m}$ above sea level, while two deciduous oaks, $Q$. ithaburensis Decaisne and $Q$. boissieri (Reuter), have scattered stands at lower altitudes and over $700 \mathrm{~m}$ 
a.s.l., respectively. Annual rainfall ranges in this area between 250 and $550 \mathrm{~mm}$.

Galls were stored in cooled bags, transferred in Italy, and put by B. Massa in small boxes at room temperature in laboratory for three years, in order to obtain adult insects. Galls were induced by 17 species of Cynipidae (for details, see Nieves-Aldrey \& Massa 2006); parasitoids emerged only from 9 of them. They were mounted, labelled and studied by us.

\section{Results and discussion}

The families of Chalcidoidea represented in the parasitoid communities associated with galls of Cynipidae in the Western Palaearctic are Eurytomidae, Torymidae, Ormyridae, Pteromalidae, Eupelmidae and Eulophidae (Askew 1984, Csóka et al. 2005). All these families, with the exception of Eupelmidae, are represented in our samples from Jordan.

We obtained 916 parasitoids from 9 species of Cynipidae, belonging to 23 species regularly inhabiting cynipid galls and to three additional species, probably only facultatively associated with them. Among them 22 were unrecorded for Jordan, and 13 of these were also new for the whole Middle East (Table 1). Moreover, 18 new host records were detected, together with 24 new plantparasitoid associations (Table 1). Two species showed a host-related variation in body pigmentation. Details on this aspect as well as on the biology of each species are given below.

\subsection{Annotated list of Chalcidoidea}

\subsubsection{Family Eurytomidae}

Eurytoma brunniventris Ratzeburg, 1852

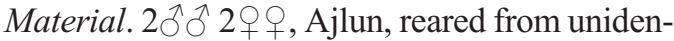
tified galls (possibly Neuroterus quercusbaccarum (Linnaeus) (sexual generation)) collected 28.IV.2000 on Q. boissieri; 49仓̋ 41우, Ajlun, ex galls Plagiotrochus quercusilicis (Fabricius) (sexual generation) collected 25.V. 1999 on Q. calliprinos.

Notes. Eurytoma brunniventris is undoubtedly a very polyphagous parasitoid in galls of Cynipini, although there are indications from re- cent molecular analyses that at least two species are confused under the name. As a larva it is an ectophagous parasitoid and can develop on the host cynipid, another parasitoid or, very commonly, on a cynipid inquiline (Synergus spp.), sometimes consuming gall tissue as well as the insect host (Askew 1961a). The species was known only for Israel in the Middle East (Pujade-Villar et al. 2003), and unrecorded on the cited plants (cf. Noyes 2003).

Eurytoma cynipsea Boheman, 1836

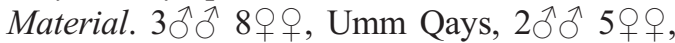
Dair Abi Said 30.IV.2000, 19, Judayta (Ajlun) 29.IV.2000, all ex galls Hedickiana levantina (Hedicke) collected in stems of Salvia sp.

Notes. This material has already been cited by Askew et al. (2006a), as a new host and plant record and for the first time in the entire Middle East. E. cynipsea was previously known as a parasitoid of several species of Aylacini (Aulacidea Ashmead, Phanacis Foerster, Timaspis Mayr, Iraella Nieves-Aldrey, Isocolus Foerster) gall-inducers on herbaceous plants, particularly of those forming galls in the flower stems of Asteraceae (cf. Askew et al. 2006a).

\section{Eurytoma infracta Mayr, 1904}

Material. $1 \delta^{\top} 4 ㅇ+$, Umm Qays, ex galls $\mathrm{He}$ dickiana levantina collected 24.V.1999 in stems of Salvia sp.

Notes. This material has already been cited by Askew et al. (2006a). The species was previously unknown for the whole Middle East and the host record is new. E. infracta was described originally from material reared from galls of Neaylax salviae (Giraud) in flower heads of Salvia officinalis Linnaeus, and it seems to be most frequently associated with galls of Aylacini on Salvia spp. (Askew et al. 2006a). It is also reported parasitizing Oxyna parietina (Linnaeus) (Tephritidae) (Klausnitzer 1968), and it has been reared from galls of Aylax minor (Hartig) and Barbotinia oraniensis (Barbotin) in seed capsules of Papaver spp. (Askew et al. 2006a).

Sycophila biguttata (Swederus, 1795)

Material. 290 , Judayta (Ajlun), ex galls Andricus grossulariae Giraud (sexual generation) collected 29.IV.2000 on Q. ithaburensis. 
Table 1. Chalcidoidea reared from galls of Cynipidae in Jordan. All chalcidoid species are new for Jordan except those marked with a star, which were already cited by Askew et al. (2006a). Species marked with a black dot are new host or plant/parasitoid associations.

\begin{tabular}{|c|c|c|c|}
\hline New records & Chalcidoid parasitoid & Cynipid host & Host plant \\
\hline Jordan & Eurytoma brunniventris & $\begin{array}{l}\text { ?Neuroterus quercusbaccarum } \hat{\partial} q \\
\text { Plagiotrochus quercusilicis } \hat{\partial} q\end{array}$ & $\begin{array}{l}\text { Quercus boissieri } \bullet \\
\text { Q. calliprinos • }\end{array}$ \\
\hline Middle East & Eurytoma cynipsea* & Hedickiana levantina $\bullet$ & Salvia sp. \\
\hline Middle East & Eurytoma infracta* & Hedickiana levantina • & Salvia sp. \\
\hline Jordan & Sycophila biguttata & Andricus grossulariae $\hat{0} \circ$ • & Q. ithaburensis • \\
\hline Jordan & Sycophila variegata & 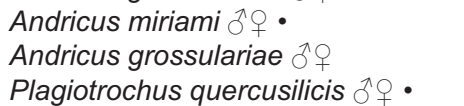 & $\begin{array}{l}\text { Q. ithaburensis } \\
\text { Q. calliprinos • }\end{array}$ \\
\hline Jordan & Megastigmus dorsalis & $\begin{array}{l}\text { Andricus grossulariae } 09 \\
\text { Dryocosmus cerriphilus } \$ 10\end{array}$ & Q. ithaburensis \\
\hline & & Plagiotrochus quercusilicis $\widehat{\jmath}+\stackrel{\bullet}{\bullet}$ & Q. calliprinos • \\
\hline Middle East & Glyphomerus tibialis* & Hedickiana levantina • & Salvia sp. \\
\hline Middle East & Torymus geranii & 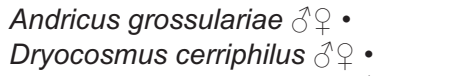 & Q. ithaburensis • \\
\hline Middle East & Torymus notatus & Plagiotrochus quercusilicis $\hat{o} q$ & Q. calliprinos • \\
\hline Jordan & Ormyrus nitidulus & Dryocosmus israeli $\widehat{\jmath} q \bullet$ & Q. ithaburensis • \\
\hline Jordan & Ormyrus pomaceus & $\begin{array}{l}\text { Andricus grossulariae } \hat{0} q \\
\text { Dryocosmus israeli } \hat{0}+{ }^{\circ} \\
\text { Plagiotrochus quercusilicis }\end{array}$ & Q. ithaburensis• \\
\hline Jordan & Cyrtoptyx robustus & $\begin{array}{l}\text { Plagiotrochus quercusilicls } \\
\text { Andricus grossulariae } \hat{0}+\bullet^{-} \\
\text {Aphelonyx cerricola }\end{array}$ & $\begin{array}{l}\text { Q. calliprinos } \\
\text { Q. ithaburensis }\end{array}$ \\
\hline Jordan & Cecidostiba fungosa & 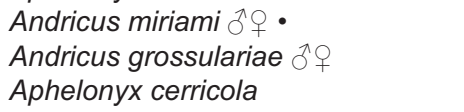 & Q. ithaburensis • \\
\hline Middle East & Cecidostiba ilicina & Plagiotrochus quercusilicis $\hat{\partial} q$ & Q. calliprinos • \\
\hline Jordan & Hobbya stenonota & 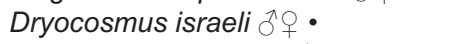 & Q. ithaburensis • \\
\hline Jordan & Mesopolobus amaenus & Andricus grossulariae $\bar{\partial}$ 우 & Q. ithaburensis • \\
\hline Middle East & Aulogymnus arsames & ?Neuroterus quercusbaccarum $\hat{\delta}$ ㅇ & Q. boissieri • \\
\hline Middle East & Aulogymnus bicolor & Plagiotrochus quercusilicis $\widehat{\jmath}+$ & Q. calliprinos • \\
\hline Middle East & Aulogymnus testaceoviridis & 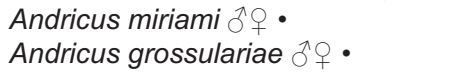 & Q. ithaburensis • \\
\hline Middle East & Pediobius lysis & Andricus quercustozae $q q$ • & Q. boissieri • \\
\hline Middle East & Pediobius rotundatus & 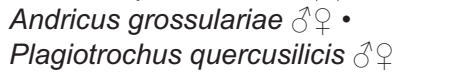 & $\begin{array}{l}\text { Q. ithaburensis• } \\
\text { Q. calliprinos• }\end{array}$ \\
\hline Middle East & Baryscapus berhidanus & Andricus quercustozae 우 & Q. boissieri \\
\hline Jordan & Baryscapus ?papaveris* & Hedickiana levantina • & Salvia sp. • \\
\hline New records & Occasional species & Inquiline host & Host plant \\
\hline $\begin{array}{l}\text { Jordan } \\
\text { Middle East } \\
\text { Jordan }\end{array}$ & $\begin{array}{l}\text { Perilampus sp. } \mathrm{nr} \text { tristis } \\
\text { Copidosoma ortyx } \\
\text { Dibrachys sp. }\end{array}$ & $\begin{array}{l}\text { Tortricidae } \\
\text { Gelechiidae } \\
\text { Gelechiidae }\end{array}$ & $\begin{array}{l}\text { Q. ithaburensis • } \\
\text { Q. ithaburensis • } \\
\text { Q. ithaburensis • }\end{array}$ \\
\hline
\end{tabular}

Notes. New host and plant records (cf. Noyes 2003). S. biguttata is the commonest Sycophila species in galls of Cynipini in which it is, usually at least, an endophagous parasitoid of the larva of the host cynipid. This species was previously known in the Middle East only for Turkey (Öncüer 1991, Gencer 2003).
Sycophila variegata (Curtis, 1831)

Material. $2 \hat{\jmath} \widehat{\jmath}$, Judayta (Ajlun) and Abu Assous, ex galls Andricus miriami Sternlicht (sexual generation) collected 29.IV.2000 and 23.V.1999 respectively on Quercus ithaburensis; 15ふえた $11+9$, Judayta (Ajlun), ex galls Andricus grossulariae (sexual generation) collected 


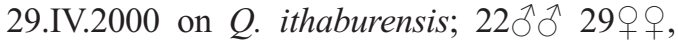
Ajlun, ex galls Plagiotrochus quercusilicis (sexual generation) collected 25.V.1999 on $Q$. calliprinos.

Notes. A. miriami and P. quercusilicis are new host records for the species, as well as the association with Q. calliprinos (cf. Noyes 2003, PujadeVillar et al. 2003). The biology of $S$. variegata is similar to that of $S$. biguttata and it is frequently reared from the same types of oak galls. It is a widespread species occurring from northern Europe to the Mediterranean and eastwards into central Asia. Specimens from the south and east of this range usually have more extensive pale colouration than those from the north and west. Jordanian specimens are very pale, especially those reared from Plagiotrochus quercusilicis galls in which the females are entirely testaceous with only a little darkening of the occiput around the foramen magnum. Females reared from Andricus grossulariae are slightly darker with black colouration about the ocelli, on the occiput and anterior surface of the pronotum, on the metanotum and anterior of the propodeum, and with a median, longitudinal black line on the gaster. In all females the characteristic pale vertical streak on the side of the fourth gastral tergite shows as a whitish area on a testaceous background. Males are more extensively darkened than their females and those reared from $A$. grossulariae galls often have, in addition, black areas on the anterior of the mesoscutum, on the scutellum mid-dorsally, the entire propodeum, parts of petiole and gaster and medially on metafemur and metatibia. Colour variations are very common in Chalcidoidea (Flanders \& Quednau 1960, Askew 1971, Barrett et al. 1988, Fisher \& La Salle 2005) and often they are linked to temperature range (Laudonia \& Viggiani 1993, Bernardo et al. 2007). Our findings fit the thermal budget adaptive hypothesis (Gibert et al. 2000), which argues that a lighter body colour, which reflects more light, is an adaptation to living in warmer places. In accord with this theory, a latitudinal cline of body pigmentation has been recorded in many insect populations (David et al. 1985, Munjal et al. 1997, de Oliveira et al. 2004), and our records are in agreement with this kind of geographical distribution, even if a host-related selective pressure is also evident. In the Middle
East area the species was already known for Iraq (Abdul-Rassoul 1980), Turkey (Öncüer 1991), and Israel (Pujade-Villar et al. 2003).

\subsubsection{Family Torymidae}

Megastigmus dorsalis (Fabricius, 1798)

Material. 10ðð 8 우우, Judayta (Ajlun), ex galls Andricus grossulariae (sexual generation) collected 29.IV.2000 on Quercus ithaburensis; 3 우, Judayta (Ajlun), ex galls Dryocosmus cerriphilus Giraud (sexual generation) collected 29.IV.2000 on $Q$. ithaburensis; $14{ }^{\lambda}{ }^{\lambda} 3$ 우우, Ajlun, ex galls Plagiotrochus quercusilicis (sexual generation) collected 25.V.1999 on Q. calliprinos.

Notes. D. cerriphilus and P. quercusilicis are new host records and the association with $Q$. calliprinos (cf. Noyes 2003, Pujade-Villar et al. 2003) is also new. A species that occurs across the Palaearctic region in the parasitoid communities of a very broad range of oak galls, perhaps associated particularly with woody galls although the contents of soft succulent and spongy galls, and spangle galls, may also be attacked (Askew 1966). The larva is ectophagous. Comments made for Sycophila variegata (above) on body pigmentation apply also to this species, as Jordanian specimens tend to be more extensively palecoloured than material from Europe, and there is host-related variation. Specimens from $D$. cerriphilus and $P$. quercusilicis are almost entirely pale, whereas those from $A$. grossulariae have a mid-dorsal metallic green stripe, similar to but rather narrower than that in material from central and northern Europe. This species was hitherto known in the Middle East only from Iran (OILB 1971), Turkey (Öncüer 1991), and Israel (Pujade-Villar et al. 2003).

\section{Glyphomerus tibialis (Förster, 1859)}

Material. 9ðえ 9우, Umm Qays 24.V.1999, $6 \widehat{\jmath} 6$ 우우, Judayta (Ajlun) 29.IV.2000, all ex galls Hedickiana levantina collected in stems of Salvia sp.

Notes. This material has already been reported by Askew et al. (2006a) and it constitutes a new host record and extension of its known range into the Middle East. This is a rather uncommon 
parasitoid with previous host records of Aulacidea subterminalis Niblett, Barbotinia oraniensis, Diastrophus mayri Reinhard, Liposthenes glechomae (Linnaeus), Neaylax salviae, Phanacis hypochoeridis (Kieffer), Rhodus cyprius (Houard) (Aylacini) and Diplolepis spinosissimae Giraud (Diplolepidini) (Askew et al. 2006a).

Torymus geranii (Walker, 1833)

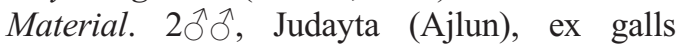
Andricus grossulariae (sexual generation) collected 29.IV.2000 on Quercus ithaburensis; $1 \hat{\sigma}$ $2 ㅇ+$, Judayta (Ajlun), ex galls Dryocosmus cerriphilus (sexual generation) collected 29.IV. 2000 on Q. ithaburensis.

Notes. New host records and parasitoid-plant association (cf. Noyes 2003). This is a polyphagous ectoparasitoid with a moderately broad host range of oak gall wasps. Species of Torymus were less well-represented in the Jordanian samples than might have been anticipated. This is the first record in the Middle East for this species (cf. Noyes 2003).

Torymus notatus (Walker, 1833)

Material. $2 \widehat{\jmath}$, Ajlun, ex galls Plagiotrochus quercusilicis (sexual generation) collected 23.V.1999 on Quercus calliprinos.

Notes. Formerly placed in the genus Syntomaspis Foerster, T. notatus belongs to a group of univoltine parasitoids, in galls of Cynipini, with relatively narrow host gall ranges (Askew 1961b). Over much of Europe, T. notatus is recorded mostly from galls of Andricus curvator Hartig (sexual generation) on Quercus robur Linnaeus, $Q$. petraea (Mattuschka) Liebl. and $Q$. faginea Lamarck, but in the Mediterranean region what appears to be the same species is known as a parasitoid of Plagiotrochus on evergreen oaks (Nieves-Aldrey 1984, Pujade-Villar \& Ros-Farre 1998). Unknown till now in the entire Middle East and for the cited Quercus species (cf. Noyes 2003).

\subsubsection{Family Ormyridae}

Ormyrus nitidulus (Fabricius, 1804)

Material. 2 우, Sammu, ex galls Dryocosmus israeli (Sternlicht) (=Chilaspis israeli (Sternlicht)) (sexual generation) collected 30.IV.2000 on catkins of Quercus ithaburensis.

Notes. A new host and plant record (cf. Noyes 2003). The genus Chilaspis Mayr has been recently synonymized with Dryocosmus Giraud by Ács et al. (2007) based on molecular phylogenetic results; all the species in the group make galls on the section Cerris oaks, as our record confirms. O. nitidulus and the following species are ectoparasitoids in cynipid galls on oak. The species is uncommon in northern Europe but increases in abundance towards the Mediterranean and eastwards across the Middle East into Asia. It is primarily a parasitoid in large, woody galls in which it seems usually to develop upon the gallinducer. The species was unrecorded for Jordan (cf. Noyes 2003), but already known for Turkey (Doganlar 1991).

Ormyrus pomaceus (Fourcroy, 1785)

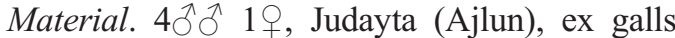
Andricus grossulariae (sexual generation) collected 29.IV.2000 on Quercus ithaburensis; 10 , Sammu, ex gall Dryocosmus israeli (sexual generation) collected 30.IV.2000 on catkins of $Q$. ithaburensis; 19, Ajlun, ex gall Plagiotrochus quercusilicis (sexual generation) collected 23.V.1999 on $Q$. calliprinos.

Notes. D. israeli is a new host record for the parasitoid, and also new is the association with the cited Quercus species (cf. Noyes 2003). Generally a smaller insect than the preceding species, it has a more diverse range of host oak galls in which it may attack inquiline Synergus and other chalcidoid parasitoids, in addition to the gall-inducers. The species was previously known from Iran in the Middle East (OILB 1971).

\subsubsection{Family Pteromalidae}

Cyrtoptyx robustus (Masi, 1907)

Material. 19 , Judayta (Ajlun), ex gall Andricus grossulariae (sexual generation) collected 29.IV.2000 on Quercus ithaburensis; $2 \hat{\jmath} 2$ ○우, Judayta (Ajlun), ex galls Aphelonyx cerricola (Giraud) collected 29.IV.2000 on Q. ithaburensis; 10 , Abu Assous, ex unidentified gall collected 23.V.1999 on Q. ithaburensis.

Notes. New host and plant records (cf. Noyes 2003). A poorly known and rather uncommon 
parasitoid which has been recorded only from galls of Cynipini, mainly the larger asexual generation galls of Andricus Hartig and Cynips Linnaeus in the Mediterranean region (cf. Noyes 2003). It was already recorded in Turkey for the Middle East (Öncüer 1991), whereas it is new for Jordan (cf. Noyes 2003).

\section{Cecidostiba fungosa (Fourcroy, 1785)}

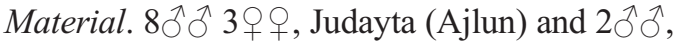
Abu Assous, ex galls Andricus miriami (sexual generation) collected 29.IV.2000 and 23.V.1999 respectively on Quercus ithaburensis; $3 \hat{\partial} \widehat{0}$ 6 우, Judayta (Ajlun), ex galls Andricus grossulariae (sexual generation) collected 29.IV.2000 on Q. ithaburensis; $1 \widehat{\jmath}$, Judayta (Ajlun), ex gall Aphelonyx cerricola collected 29.IV.2000 on $Q$. ithaburensis.

Notes. A. miriami is a new host record for this species, and also new is the association with $Q$. ithaburensis (cf. Noyes 2003). C. fungosa is a polyphagous parasitoid in Cynipini galls in Jordan, as it is over most of Europe. In Britain, however, before the advent of Andricus quercuscalicis (Burgsdorf) it was apparently a host gall specific parasitoid of Biorhiza pallida (Olivier) (sexual generation). Previously recorded only for Israel in the Middle East (cf. Noyes 2003, PujadeVillar et al. 2003).

Cecidostiba ilicina Nieves-Aldrey \& Askew, 1988

Material. $5 \AA 1$, Ajlun, ex galls Plagiotrochus quercusilicis (sexual generation) collected 25.V.1999 on Quercus calliprinos.

Notes. Described by Nieves-Aldrey \& Askew (1988) from galls of Plagiotrochus quercusilicis and more recently reported for $P$. australis (Mayr) (Garrido Torres \& Nieves-Aldrey 1999) and from galls of sexual generation Biorhiza pallida (Bellido \& Pujade-Villar 1999). The present record is the first for the species outside the Iberian Peninsula and on Q. calliprinos (cf. Noyes 2003); however, it was already cited on $Q$. coccifera Linnaeus (Garrido Torres \& NievesAldrey 1999), of which Q. calliprinos is considered a subspecies or a variety by some botanists.
Hobbya stenonota (Ratzeburg, 1848)

Material. 3ðึત 8 우, Sammu, ex galls Dryocosmus israeli (sexual generation) collected 30.IV.2000 on catkins of Quercus ithaburensis; $2 \circ$ 으, Ajlun, ex unidentified gall collected 23.V.1999 on Q. ithaburensis.

Notes. A new host and plant record. H. stenonota is another moderately polyphagous ectoparasitoid in galls of Cynipini; it has also been reared, exceptionally, from the rose gall of Diplolepis mayri (Schlechtendal) in Iran (Askew et al. 2006b). It was known previously in the Middle East from Iran (Askew et al. 2006b), and Turkey (Öncüer 1991).

\section{Mesopolobus amaenus (Walker, 1834)}

Material. $3+$ q , Judayta (Ajlun), ex galls Andricus grossulariae (sexual generation) collected 29.IV.2000 on Quercus ithaburensis.

Notes. M. amaenus is associated with many species of oak gall wasps, especially those inducing bud galls such as the larger Andricus species (Askew 1961c). The association with $Q$. ithaburensis is new (cf. Noyes 2003). Exceptionally, it is known from Iran as a parasitoid in rose galls of Diplolepis mayri (Askew et al. 2006b). In the Middle East recorded only from Israel (PujadeVillar et al. 2003), and Iran (Haeselbarth 1983, Askew et al. 2006b).

\subsubsection{Family Eulophidae}

\section{Aulogymnus arsames (Walker, 1838)}

Material. 9 우, Ajlun, ex unidentified leaf galls (possibly Neuroterus quercusbaccarum (sexual generation)) collected 28.IV.2000 on Quercus boissieri.

Notes. Aulogymnus species are mostly parasitoids of Cynipini with a more or less restricted host gall range and developing as larvae externally on the gall wasp larvae (Askew 1961d). $A$. arsames is a univoltine species, at least in central and northern Europe, with a relatively small host gall range. It is frequent in galls of sexual generation Neuroterus quercusbaccarum in Britain, which supports the suggestion of Nieves-Aldrey \& Massa (2006) that the unidentified galls from Quercus boissieri in Jordan are of this species. This is the first record on this plant and for the whole Middle East (cf. Noyes 2003). 
Aulogymnus bicolor (Askew, 1975)

Material. 11ડ̄ð 3 우, Ajlun, ex galls Plagiotrochus quercusilicis (sexual generation) collected 23.-25.V.1999 on Quercus calliprinos.

Notes. This very distinctive species has previously been recorded only from the Iberian Peninsula (Askew 1975). It appears to be associated only with galls of Plagiotrochus (Askew pers.obs.). The association with the cited Quercus species is new (cf. Noyes 2003).

Aulogymnus testaceoviridis (Erdös, 1961)

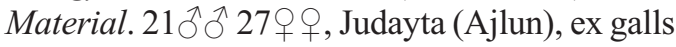
Andricus miriami (sexual generation) collected 29.IV.2000 on Quercus ithaburensis; $4{ }^{\lambda}{ }^{\lambda} 6$ 우, Judayta (Ajlun), ex galls Andricus grossulariae (sexual generation) collected 29.IV.2000 on $Q$. ithaburensis.

Notes. New host and plant records (cf. Noyes 2003). A. testaceoviridis was known previously as a central European species, recorded from galls of A. multiplicatus Giraud (sexual generation) in Hungary (Melika et al. 2002) and A. quercusramuli (Linnaeus) (sexual generation) in Romania (Andriescu \& Schiopu 2002). Previously unknown outside Hungary and Romania (cf. Noyes 2003).

Pediobius lysis (Walker, 1839)

Material. 19, Ajlun, ex gall Andricus quercustozae (Bosc) (asexual generation) collected 29.X.1999 on Quercus boissieri.

Notes. New host and plant records (cf. Noyes 2003). However, Pediobius lysis is primarily a parasitoid of asexual spangle galls of Neuroterus (in Europe), and its presence in a gall of Andricus quercustozae is probably accidental. Species of Pediobius are small endoparasitoids and, so far as is known, attack only larvae of the gall-inducer, therefore needing to oviposit into a young host larva in a small gall. Unrecorded in the whole Middle East before now (cf. Noyes 2003).

Pediobius rotundatus (Fonscolombe, 1832)

Material. 1ㅇ, Judayta (Ajlun), ex gall Andricus grossulariae (sexual generation) collected

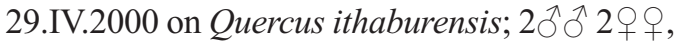
Ajlun, ex galls Plagiotrochus quercusilicis (sexual generation) collected 25.V.1999 on Quercus calliprinos.
Notes. This is a bivoltine species, a common endoparasitoid of Plagiotrochus larvae, especially $P$. quercusilicis. The rearing from Andricus grossulariae constitutes a new host record as well as are new the associations with the cited Quercus species (cf. Noyes 2003). Previously unknown in the Middle East (cf. Noyes 2003).

Baryscapus berhidanus (Erdös, 1954)

Material.1 9 , Ajlun, ex gall Andricus quercustozae (asexual generation) collected 29.V.1999 on Quercus boissieri.

Notes. Described from specimens reared from galls of Andricus quercustozae (asexual generation) collected in Hungary, but more recently associated with several other species of Andricus (cf. Noyes 2003). Previously unrecorded outside Europe and on Q. boissieri (cf. Noyes 2003).

Baryscapus ?papaveris Graham, 1991

Material. About 480 specimens (approximate sex ratio 1ठ:20우), Umm Qays, ex galls Hedickiana levantina collected 23-24.V.1999 on Salvia sp.

Notes. B. papaveris was described from galls of Aylax papaveris (Perris) in Papaver seed capsules collected in France (Graham 1991). The Jordanian material resembles $B$. papaveris reared from A. minor and A. papaveris galls in Spain (cf. Nieves-Aldrey \& Askew 2002), but small morphological differences cause us to hesitate to firmly designate it as $B$. papaveris. This material has already been reported by Askew et al. (2006a). No Baryscapus species was previously known for Jordan (cf. Noyes 2003).

\subsection{Other species of Chalcidoidea}

The species listed above are considered to be obligatory parasitoids of the cynipid gall-inducers, or of their inquilines, or of other parasitoids. In addition, some other Chalcidoidea were reared from the galls. These are regarded as casual or accidental members of the gall community, not attacking the regular inhabitants of the galls but probably finding their hosts among the several diverse insects that use cynipid galls facultatively as shelters. 


\subsubsection{Family Perilampidae}

Perilampus sp. nr tristis Mayr, 1905

Material. $3 \overbrace{}^{\lambda} 4 ㅇ$, Judayta (Ajlun), ex galls Andricus cecconii Kieffer (sexual generation) collected 29.IV.2000 on Quercus ithaburensis; 19 , Judayta (Ajlun), ex gall Aphelonyx cerricola collected 29.IV.2000 on Q. ithaburensis; 1 , Ajlun, ex unidentified gall collected 24.V.1999 on Q. ithaburensis.

Notes. Perilampus tristis is a parasitoid of microlepidoptera larvae (Bouček 1977) and it is thought that the specimens reared from Jordanian galls could have developed upon larval Tortricidae. No Perilampus species was previously known for Jordan, although P. tristis is recorded for many countries of the Middle East (cf. Noyes 2003).

\subsubsection{Family Encyrtidae}

Copidosoma ortyx Guerrieri \& Noyes, 2005

Material. 290 Judayta (Ajlun), ex gall Andricus miriami (sexual generation) collected 29.IV.2000 on Quercus ithaburensis.

Notes. These specimens probably emerged from a Gelechiidae inquiline, which is the first host record for this species. C. ortyx was described from Portugal and hitherto known only from that country (Guerrieri \& Noyes 2005).

\subsubsection{Family Pteromalidae}

Dibrachys sp.

Material. 1엉 Judayta (Ajlun), ex gall Andricus miriami (sexual generation) collected 29.IV.2000 on Quercus ithaburensis.

Notes. Species of Dibrachys are primary or secondary parasitoids of holometabolous insects. The most abundant Holarctic species, D. cavus (Walker) is 'a very polyphagous species' (Graham 1969), but most often reared as a secondary parasitoid from cocoons of Ichneumonoidea parasitic upon Lepidoptera. The Jordanian specimen is either D. cavus or a species closely allied to it, and probably developed upon a larval Gelechiidae. No Dibrachys is recorded for Jordan, although the very similar D. boarmiae (Walker) is known from Iran and Turkey (cf. Noyes 2003).
Acknowledgements. We are grateful to José Nieves-Aldrey for advice on cynipid taxonomy, to Emilio Guerrieri and John Noyes for the identification of Copidosoma ortyx. This study was funded by "Fondi di Ateneo-Università di Palermo: Entomocenosi di ecosistemi agrari e forestali" (Responsible: Bruno Massa).

\section{References}

Abdul-Rassoul, M. S. 1980: New species of Sycophila Walker from Iraq (Hymenoptera, Eurytomidae). Ann. Hist.-Nat. Mus. Natl. Hung. 72: 281-284.

Ács, Z., Melika, G., Pénzes, Z., Pujade-Villar, J., \& Stone, G. 2007: The phylogenetic relationships between Dryocosmus, Chilaspis and allied genera of oak gallwasps (Hymenoptera, Cynipidae: Cynipini). — Syst. Entomol. 32: 70-80.

Andriescu, I. D. \& Schiopu, I. 2002: The parasitoid complex of oak gallwasp Andricus quercusramuli (L.) 우 $\widehat{\sigma}$ (Hymenoptera: Cynipidae) in south east Romania. In: Melika, G. \& Thuróczy, C. (eds.), Parasitic Wasps: evolution, systematics, biodiversity and biological control: 362-367. Agroinform, Budapest. 480 pp.

Askew, R. R. 1961a: On the biology of the inhabitants of oak galls of Cynipidae (Hymenoptera) in Britain. Trans. Soc. Br. Entomol. 14: 237-268.

Askew, R. R. 1961b: On the Palaearctic species of Syntomaspis Förster (Hym., Chalcidoidea, Torymidae). Entomologist's monthly Magazine 96 (1960): 184 191.

Askew, R. R. 1961c: A study of the biology of species of the genus Mesopolobus Westwood (Hymenoptera: Pteromalidae) associated with cynipid galls on oak. Trans. Soc. Br. Entomol. 113: 155-173.

Askew, R. R. 1961d: The biology of the British species of the genus Olynx Förster (Hymenoptera: Eulophidae), with a note on seasonal colour forms in the Chalcidoidea. - Proc. R. Soc. Lond. 36: 103-112.

Askew, R. R. 1966: Observations on the British species of Megastigmus Dalman (Hym., Torymidae) which inhabit cynipid oak galls. - Entomologist 99: 124-128.

Askew, R. R. 1971: Parasitic insects. — Heinemann Educational Books, London. 316 pp.

Askew, R. R. 1975: Some Chalcidoidea from Majorca, with descriptions of two new species (Hymenoptera). — Eos. Revista Española di Entomologia 49: 16-18.

Askew, R. R. 1984: The biology of gall wasps. In: Ananthakrishnan, T.N. (ed.), The biology of gall insects: 223-271 - Edward Arnold, Baltimore. 362 pp.

Askew, R. R., Plantard, O., Gómez, J. F., Hernandez Nieves, M. \& Nieves-Aldrey, J. L. 2006a: Catalogue of parasitoids and inquilines in galls of Aylacini, Diplolepidini and Pediaspidini (Hym., Cynipidae) in the West Palaearctic. - Zootaxa 1301: 1-60.

Askew, R. R., Sadeghi, S. E. \& Tavakoli, M. 2006b: Chalcidoidea (Hym.) in galls of Diplolepis mayri (Hym., Cynipidae) in Iran, with the description of a new speci- 
es of Pseudotorymus Masi (Hym., Torymidae). — Entomologist's monthly Magazine 142: 1-6.

Barrett, B. A., Brunner, J. F. \& Turner, W. J. 1988: Variations in color, size, and thoracic morphology of Pnigalio species (Hymenoptera: Eulophidae) parasitizing Phyllonorcter elmaeella (Lepidoptera: Gracillariidae) in Utah and Washington. - Ann. Entomol. Soc. Am. 81(3): 517-521.

Bellido, D. \& Pujade-Villar, J. 1999: Comparicón de cadenzas tróficas asociados a agallas de cinipidos (Hym.: Cynipidae) en dos ambientos distintos. - Boletin de la Asociación Española de Entomologia 23: 265-275.

Bernardo, U., Pedata, P. A. \& Viggiani, G. 2007: Phenotypic plasticity of pigmentation and morphometric traits in Pnigalio soemius (Hymenoptera: Eulophidae). Bull. Entomol. Res. 97: 1-10.

Bouček, Z. 1977: A faunistic review of the Yugoslavian Chalcidoidea (Parasitic Hymenoptera). - Acta entomologica Jugoslavica 13, supplementum: 1-145.

Csóka, G., Stone, G. N. \& Melika, G. 2005: Biology, Ecology, and Evolution of Gall-inducing Cynipidae. In: Raman, A., Schaefer, C. W. \& Withers, T. M. (eds.), Biology, Ecology, and Evolution of Gall-inducing Arthropods: vol. 2, 573-642. Science Publishers Inc., Enfield. 817 pp.

David, J. R., Capy, P., Payant, V. \& Tsakas, S. 1985: Thoracic trident pigmentation in Drosophila melanogaster: differentiation of geographical populations. - Genet. Sel. Evol. 17: 211-223.

de Oliveira, C. M., Lopes, J. R. S., Dias, C. T. D. S. \& Nault, L. R. 2004: Influence of latitude and elevation on polymorphism among populations of the corn leafhopper, Dalbulus maidis (DeLong and Wolcott) (Hemiptera: Cicadellidae), in Brazil. - Environ. Entomol. 33, 1192-1199.

Doganlar, M. 1991: Systematic position of some taxa in Ormyridae and description of a new species in Ormyrus from Turkey and a new genus in the family (Hymenoptera, Chalcidoidea). — Turkiye Entomolojii Dergisi 15: 1-13.

Fisher, N. \& La Salle, J. 2005: A new species of Neochrysocharis Kurdjumov (Hymenoptera: Eulophidae), a parasitoid of serpentine leafminers (Diptera: Agromyzidae) in Southeast Asia. — Zootaxa 1044: 27-34.

Flanders, S. E. \& Quednau, W. 1960: Taxonomy of the genus Trichogramma (Hymenoptera, Chalcidoidea, Trichogrammatidae). — Entomophaga 5(4): 285-294.

Garrido Torres, A. M. \& Nieves-Aldrey, J. L. 1999: Pteromálidos de la Comunidad de Madrid: faunistica y catálogo (Hymenoptera, Chalcidoidea, Pteromalidae). Graellsia 55: 9-147.

Gencer, L. 2003: The chalcidoid parasitoids of Diplolepis mayri Schld. (Hymenoptera: Cynipidae), a pest of Rosa canina L. in Sivas province. — Türkiye Entomoloji Dergisi 27(2): 108.

Gibert, P., Moreteau, B. \& David, J. R. 2000: Developmental constraints on an adaptive plasticity: reaction norms of pigmentation in adult segments of Drosophila melanogaster. - Evol. Dev. 2: 249-260.
Graham de V., M. W. R. 1969: The Pteromalidae of northwestern Europe (Hymenoptera: Chalcidoidea). Bull. Br. Mus. Nat. Hist., Entomol. supplement 16: 1908.

Graham de V., M. W. R. 1991: A reclassification of the European Tetrastichinae (Hymenoptera: Eulophidae): revision of the remaining genera. - Mem. Amer. Entomol. Inst. 49: 1-322.

Guerrieri, E. \& Noyes, J. S. 2005: Revision of the European species of Copidosoma Ratzeburg (Hymenoptera: Encyrtidae), parasitoids of caterpillars (Lepidoptera). — Syst. Entomol. 30: 97-174.

Haeselbarth, E. 1983: Determination list of entomophagous insects No 9. - IOBC/WPRS Bulletin 6(1): 149.

Klausnitzer, B. 1968: Zur Kenntnis der Parasiten von Oxyna parietina (L.) (Diptera, Trypetidae). — Entomologische Abhandlungen, Dresden 36(2): 37-40.

Laudonia, S. \& Viggiani, G. 1993: Effetto della temperatura sulla colorazione degli adulti di Encarsia partenopea Masi (Hymenoptera: Aphelinidae). - Boll. Lab. Entomol. agr. "Filippo Silvestri” 50: 141-146.

Melika, G., Csóka, G., Stone, G. N. \& Schönrogge, K. 2002: Parasitoids reared from galls of Andricus aestivalis Giraud, A. grossulariae Giraud, A. multiplicatus Giraud and $A$. vindobonensis Muellner in Hungary (Hymenoptera: Cynipidae). — Folia Entomologica Hungarica 63: 105-112.

Munjal, A. K., Karan, D., Gibert, P., Moreteau, B., Parkash, R., \& David J. R. 1997: Thoracic trident pigmentation in Drosophila melanogaster: latitudinal and altitudinal clines in Indian populations. - Genet. Sel. Evol. 29: 601-610.

Nieves-Aldrey, J. L. 1984: Observaciones sobre los torímidos (Hym., Chalcidoidea, Torymidae) asociados con agallas de cinípidos (Hym., Cynipidae) sobre Quercus spp. en la zona centro-occidental de España. — Bol. Asoc. Esp. Entomol. 8: 121-134.

Nieves-Aldrey, J. L. \& Askew, R. R. 1988: A new species of Cecidostiba Thomson (Hym., Pteromalidae), a key to species of the genus and rearing records of other Pteromalidae associated with oak gall wasps (Hym., Cynipidae). - Entomologist's monthly Magazine 124: $1-5$.

Nieves-Aldrey, J. L. \& Askew, R. R. 2002: Calcidoideos (Hym., Chalcidoidea) asociados a agallas de Aylacini y Diplolepidini (Hym., Cynipidae) en España. - Bol. Asoc. Esp. Entomol. 26: 11-37.

Nieves-Aldrey, J. L. \& Massa, B. 2006: Contribution to the knowledge of the Cynipidae (Hymenoptera) of Jordan. - Zoology in the Middle East 37: 73-82.

Noyes, J.S. 2003: Universal Chalcidoidea Database. [www document] URL www.nhm.ac.uk/entomology/chalcidoids/index.html (accessed 25.I.2007).

OILB. 1971. Liste d'identification des entomophages 8.OILB, Genève. 49 pp.

Öncüer, C. 1991: A catalogue of the parasites and predators of insect pests of Turkey. - Publication of Univ. of Ege, Fac. of Agriculture, Ege. 354 pp. [In Turkish]. 
Pujade-Villar, J. \& Ros-Farre, P. 1998: Inquilinos y parásitos de las agallas del género Plagiotrochus Mayr colectadas en el Nordeste de la Península Ibérica. - Bol. Asoc. Esp. Entomol. 22: 115-143.

Pujade-Villar, J., Ros-Farré, P. \& Melika, G. 2003: Revision of the genus Chilaspis Mayr, 1881 (Hymenopte- ra: Cynipoidea: Cynipidae). — Ann. Soc. Entomol. Fr. (n.s.) 39(2): 167-178.

Stone, G. N., Schönrogge, K., Atkinson, R. J., Bellido, D. \& Pujade-Villar, J. 2002: The Population Biology of Oak Gall Wasps (Hymenoptera: Cynipidae). - Annu. Rev. Entomol. 47: 633-668. 